\title{
Reflections on the fabrication of musical folklore in Kenya from the early 1920 s to the late 1970 s
}

\section{(2) OpenEdition}

Journals

Electronic version

URL: https://journals.openedition.org/eastafrica/287

DOI: $10.4000 /$ eastafrica.287

ISSN: 2790-1076

Publisher

IFRA - Institut Français de Recherche en Afrique

Printed version

Date of publication: 1 May 2015

ISSN: 2071-7245

Electronic reference

"Reflections on the fabrication of musical folklore in Kenya from the early 1920s to the late 1970s", Les Cahiers d'Afrique de l'Est / The East African Review [Online], 50 | 2015, Online since 21 September 2022, connection on 10 October 2022. URL: http://journals.openedition.org/eastafrica/287 ; DOI: https:// doi.org/10.4000/eastafrica.287

This text was automatically generated on 10 October 2022

All rights reserved 


\section{Reflections on the fabrication of musical folklore in Kenya from the early 1920 s to the late 1970 s}

This article has been removed at the request of the author. The previously published article did not correspond to the author's final version. We apologise to both the author and the readers. 